Article

\title{
Biocleaning to Remove Graffiti: A Real Possibility? Advances towards a Complete Protocol of Action
}

\author{
Patricia Sanmartín $1, *$ (i) and Pilar Bosch-Roig ${ }^{2}$ \\ 1 Departamento de Edafoloxía e Química Agrícola. Facultade de Farmacia, \\ Universidade de Santiago de Compostela, 15782 Santiago de Compostela, Spain \\ 2 Instituto de restauración del Patrimonio, Universitat Politècnica de València, 46022 Valencia, Spain; \\ pboschroig@gmail.com \\ * Correspondence: patricia.sanmartin@usc.es; Tel.: +34-881-814-984
}

Received: 31 December 2018; Accepted: 1 February 2019; Published: 8 February 2019

\begin{abstract}
The first academic studies on the use of microorganisms in cleaning procedures appeared in the late 1980s/early 1990s. In the past thirty years, most of such studies have addressed the removal of nitrate and sulphate salts and organic matter from surfaces by using non-pathogenic anaerobic microorganisms, mainly sulphate-reducing bacteria. The successful use of microbes in the removal of graffiti paint remains, however, a work in progress. Biocleaning surfaces to remove graffiti is not a simple task, because of the complex chemical composition of graffiti paints. This study looks at ways of improving the bioremoval of graffiti and presents the latest findings regarding different methodological aspects of cleaning natural and man-made stone. Granite and concrete substrates were coated with silver and black graffiti spray paints for comparison of the efficacy of the biocleaning method on these different materials. Visual and microscopic examination along with colour and infrared measurements made after application of the bacterial strains tested (previously shown to be suitable candidates for bioremoval of graffiti) revealed remarkably successful results. The findings presented thus represent progress in the development of a biocleaning protocol applicable to the in-situ removal of graffiti. Important improvements have been made regarding the time of treatment, which has been reduced by up to 20 days, and the use of a culture medium enriched with powdered graffiti, which facilitates and accelerates the adaptation of the microorganisms to the target surface.
\end{abstract}

Keywords: biocleaning; cultural heritage; microorganisms; novel methods; graffiti spray paint; stone

\section{Introduction}

Stone structures undergo deterioration due to various factors such as biological colonization, air pollution, weathering caused by deleterious treatment or lighting, and the presence of undesirable graffiti. Graffiti can be found on all types of surfaces, including façades, walls, urban furniture, and subways. Graffiti can, therefore, affect various types of material, such as glass, metal, and stone, although walls are the structures most commonly (42.7\%) affected [1]. Graffiti cause disfigurement of the urban fabric and also generate a certain degree of pollution due to the associated emissions, chiefly based on volatile organic compounds. Many affected sites are considered deteriorated and thus lose some of their economic value. In the preservation of public spaces and historic buildings, graffiti removal (i.e., removal of aerosol spray paint, the most commonly used staining agent) requires a huge financial outlay by local governments and agencies; e.g., in 2008, the cost of removing graffiti from buildings in the city of Santiago de Compostela (Spain) amounted to more than $€ 150,000$ [2].

Against this background, some regional, national and European projects have recently been developed to develop anti-graffiti coatings and methods of graffiti removal. The GRAFFITAGE project (2005-2008) aimed to develop new anti-graffiti coating systems (based on filmogen latex and 
hydrophobized polycations) in order to prevent damage to historical buildings [3]. The EFFACEUR project (2011-2012) was developed by a consortium of small and medium sized businesses with the objective of developing, scaling and transferring the new anti-graffiti project to the market [4]. The BioRemoGraf project (2013-2015) was a pioneering study aimed at developing a biological method based on the use of microorganisms to remove graffiti from construction materials while leaving the substrate undamaged, as none of the currently available cleaning methods (chemical, mechanical and/or laser) are capable of removing graffiti without also affecting the underlying substrate in some way [5,6]. Similarly, the SICH PRIN project (2010-2011) included a line of research involving the bioremoval of graffiti by new and eco-sustainable methods based on enzymatic cleaning with lipase [7].

The removal of graffiti by using microorganisms (i.e., bacteria and fungi) is very difficult because of the variable composition of graffiti paint and the interactions between the paint and the underlying substrate. Graffiti paint comprises various different types of pigments, binders, solvents, additives and other minor components. Thus, the pigments can be inorganic or organic, and binders can be natural (derived from plants or animals), synthetic (mostly resins such as alkyds, acrylics, and polyvinyl acetates,) or semi-synthetic polymers (e.g., nitrocellulose). Hydrocarbon solvents, oxygenated solvents and water are commonly used. Graffiti paints also include small quantities of many different additives such as plasticizers, dispersants, $\mathrm{pH}$ buffers and biocides. Furthermore, the strains of microorganisms used in the cleaning procedure must demonstrate a high level of tolerance to graffiti and must have a deteriorating impact on the paint, preferably under aerobic conditions. These requirements are difficult to meet, as most microorganisms found on paint films are actually aerial contaminants that are not involved in the degradation process [8].

Despite the above-mentioned difficulties, four studies have obtained successful results regarding the bioremoval of graffiti. Giacomucci et al. [9] tested the ability of Desulfovibrio desulfuricans ATCC 13,541 to degrade nitrocellulose-based binder and red graffiti spray paint applied to glass slides incubated for 49 days under anaerobic conditions. Sanmartín et al. [10] reported the successful isolation of environmental microorganisms and the capacity of these to degrade black graffiti spray paint (containing alkyd and polyester resin binders) applied to glass slides incubated for 25 days under aerobic conditions. Nine bacterial strains belonging to the genera Arthrobacter, Bacillus, Gordonia, Microbacterium, Pantoea and Pseudomonas and one fungal strain belonging to the genus Alternaria have also shown to be effective biocleaning agents [10]. In a later study, Sanmartín et al. [11] evaluated the capacity of eight species of aerobic, mesophilic and culturable bacteria, obtained from the American Type Culture Collection (ATCC) and the German Deutsche Sammlung von Mikroorganismen und Zellkulturen GmbH (DSMZ) collections of microorganisms, to remove graffiti from substrates. Among these species, Aerobacter aerogenes ATCC 13048, a mixture of Pseudomonas picketti and an unidentified Bacillus species ATCC 53922, and Comamonas sp. ATCC 700,440 demonstrated high levels of tolerance to the presence of the graffiti paint and some ability to degrade the surface of painted test pieces. Finally, Germinario et al. [7] developed a method based on the catalytic activity of lipases for the removal of marker pen inks (also used by graffiti artists).

Despite the promising results, further laboratory-based biocleaning assays are needed to develop a standardised protocol of action. Thus, culture conditions such as the medium composition, temperature and $\mathrm{pH}$, must be taken into consideration in order to optimize the growth of the microorganisms and reduce the time required to carry out the process. A practically feasible method of applying the treatment to stone material is also required.

In the present study, some of these methodological advances have been addressed in relation to the biocleaning of natural and man-made stone materials to remove graffiti. Three species of bacteria (Pseudomonas stutzeri 5190, Aerobacter aerogenes 13048, and Comamonas sp. 700440), previously identified as good candidates for bioremediation purposes [11,12], were grown with (and thus adapted to) powdered graffiti and applied to granite and concrete substrates coated with silver and black graffiti spray paints to test the degradative capacity of the bacteria. Different methods of applying the treatments were tested by evaluating two different carriers (cotton and $2 \%$ agar) and two application 
solutions (M9 mineral medium and water) towards the development of a practically feasible method of in situ graffiti removal.

\section{Materials and Methods}

\subsection{Bacterial Selection, Media and Culture Protocols for the Adaptation of the Microorganisms}

Three aerobic bacteria were selected in order to test new methodological aspects of the bioremoval of graffiti: Pseudomonas stutzeri 5190 (DSMZ, Braunschweig, Germany) [12], Aerobacter aerogenes 13,048 (ATCC, Manassas, VI, USA) [11] and Comamonas sp. 700,440 (ATCC, USA) [11]. The use of aerobic microbes represents a great advantage compared to the use of anaerobic bacteria, which usually require rather more restrictive conditions.

The selected bacteria were grown in the laboratory on Nutrient Agar (NA, a general medium containing $0.5 \%$ peptone, $0.3 \%$ yeast extract, $0.5 \%$ sodium chloride, and $1.5 \%$ agar, in distilled water) at $28{ }^{\circ} \mathrm{C}$ for $24 \mathrm{~h}$. One colony of each strain was then grown in a $10 \mathrm{~mL}$ tube containing Nutrient Broth culture medium (NB, a general liquid medium identical to the above medium, but without agar) at $28^{\circ} \mathrm{C}$. For each bacterial suspension, the number of colony forming units (CFUs) was determined by serial dilution, and the bacterial biomass was homogenized to $1.0 \times 10^{9} \mathrm{CFU} / \mathrm{mL}$ (Figure 1).

The ability of the selected bacterial cultures to degrade graffiti was tested in the laboratory. A specific selective medium based on an $\mathrm{M} 9$ mineral medium (M9 broth $\left(75.2 \mathrm{~g} / \mathrm{L} \mathrm{Na}_{2} \mathrm{HPO}_{4}-2 \mathrm{H}_{2} \mathrm{O}\right.$, $30 \mathrm{~g} / \mathrm{L} \mathrm{KH}_{2} \mathrm{PO}_{4}, 5 \mathrm{~g} / \mathrm{L} \mathrm{NaCl}, 5 \mathrm{~g} / \mathrm{L} \mathrm{NH} \mathrm{Nl}_{4} \mathrm{Cl}+\mathrm{MgSO}_{4}(1 \mathrm{M})+\mathrm{CaCl}_{2}(1 \mathrm{M})$ ) was supplemented with powdered graffiti (black or silver) as a selective agent (Figure 2).

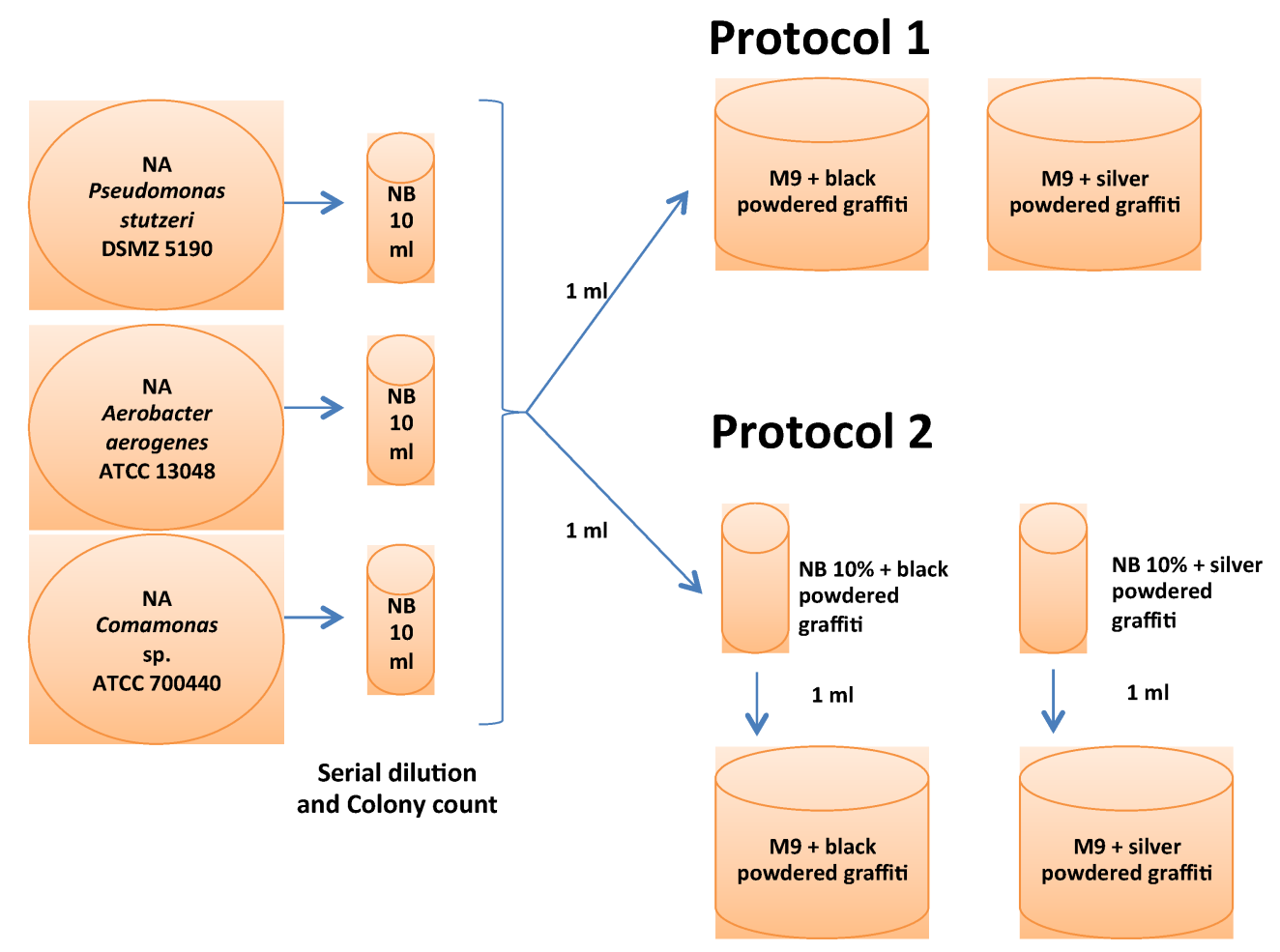

Figure 1. Schematic diagram of the experimental set-up for testing the culture protocols.

In order to optimize the selected bacterial growth, two protocols were tested (Figure 1). Previous findings regarding biocleaning were taken into account in developing both protocols. Some authors have tested protocols based on the use of general culture media supplemented with the substance to be cleaned. For example, Ranalli et al. [13] used Plate Count Agar supplemented with animal glue for the bioremoval of animal glue from wall paintings. By contrast, other authors used mineral media supplemented with the substance to be cleaned. For example, Bosch-Roig et al. and 
Ranalli et al. used M9 mineral medium supplemented with animal glue to clean glue deposits [14,15] and nitrate broth to clean nitrate salts [16]. Studies specifically involving the bioremoval of graffiti used both culture media strategies: Mineral salt solution and Trypticase Soy Broth (TSB) [10,11]. On the basis of the findings of these studies, we tested two growth protocols: One with a mineral salt solution (M9) supplemented with powdered graffiti (Protocol 1) and another with a general culture medium (Nutrient Broth) supplemented with powdered graffiti (Protocol 2). The approach used in protocol 1 was of particular interest because it assumes that bacteria can be grown with only powdered graffiti (Figure 2) as a source of carbon.

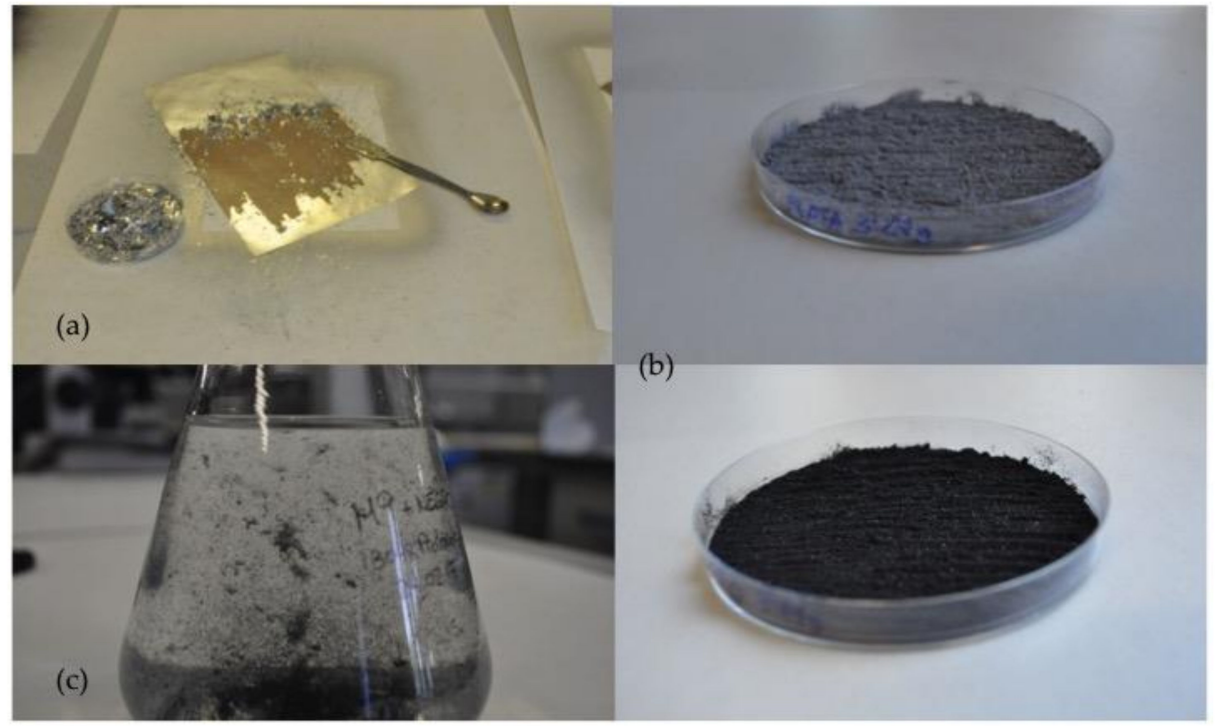

Figure 2. (a) Preparation of powdered graffiti; (b) silver and black powdered graffiti paints; (c) application solution supplemented with black powdered graffiti paint.

Protocol 1:1 mL of each bacterial suspension was added to an M9 mineral medium broth enriched with $0.1 \mathrm{~g} / 100 \mathrm{~mL}$ powdered graffiti (black and silver separately) and incubated at $28^{\circ} \mathrm{C}$ for 20 days.

Protocol 2:1 mL of each bacterial suspension was added to 10\% Nutrient Broth (NB) enriched with $0.1 \mathrm{~g} / 100 \mathrm{~mL}$ powdered graffiti (black and silver separately) and incubated at $28{ }^{\circ} \mathrm{C}$ for three days. Then, $1 \mathrm{~mL}$ of the growing culture was then added to an $\mathrm{M} 9$ mineral medium broth enriched with $0.1 \mathrm{~g} / 100 \mathrm{~mL}$ powdered graffiti (black and silver separately) and incubated at $28^{\circ} \mathrm{C}$ for 20 days. This is a two-step protocol requiring a growth period of 23 days.

For each protocol and each colour of graffiti paint, control set-ups without bacteria were included in the experiments. Powdered graffiti was prepared as described in Section 2.2. Bacterial growth was evaluated by serial dilution of the suspensions every three days during the experimental period. The $\mathrm{pH}$ of the culture medium was 8 .

\subsection{Preparation of Powdered Graffiti and Painted Natural and Man-Made Stone Specimens}

A black, non-metallic spray paint ( $R$-9011 from Montana Colors, Barcelona, Spain) and a silver, metallic spray paint (Silver Chrome from Montana Colors), both previously used in studies of laser removal of graffiti from granite [17,18], were selected for this study. Alkyd and polyester resins or varnishes appear in the black paint and polyethylene-type polymers with particles of aluminium and, to a lesser extent iron, appear in the silver paint $[17,18]$.

Powdered graffiti was prepared for the experiments by scratching thick layers of dried, hardened (after $48 \mathrm{~h}$ ) graffiti from a non-stick plastic surface (Figure 2a) and then homogenizing the paint thus removed with a hand-held blender (Figure $2 b$ ). This protocol was performed separately with each selected colour of graffiti paint. The powdered graffiti was sterilized using formaldehyde $37 \% v / v$ vapour, following the protocol described in Sanmartín et al. [10]. 
A slightly weathered granite and a man-made concrete were selected as support for the graffiti paints (Figure 3). Silvestre granite, quarried in the surroundings of Vigo (Pontevedra, Spain), is of great commercial value in the area because it is currently one of the granites mostly commonly used in civil and heritage buildings. It is two-mica adamellitic granite, of equigranular panallotriomorphic texture, and is white medium-grained with some ochre spots owing to biotite weathering. The modal composition comprises quartz $(29 \%)$, feldspar-K $(26 \%)$, plagioclases $(24 \%)$, biotite $(8 \%)$, moscovite $(8 \%)$ and chlorite (3.5\%) as the main minerals [19].

Cement paste was prepared specifically for this study by a local construction company (Breixo S.L. Obras e Servicios, Santiago de Compostela, Spain), in accordance with EN 197-1 [20]. The paste was thus made using a proportion of 1 volume cement to 4 volumes of sand (i.e., $364 \mathrm{~kg} / \mathrm{m}^{3}$ cement: $1450 \mathrm{~kg} / \mathrm{m}^{3}$, sand: $240 \mathrm{~kg} / \mathrm{m}^{3}$ water). The cement and sand were analysed by X-ray diffraction (XRD) (Figure 4). Portland cement (PC) clinker was used to produce the concrete (Figure 4a), as indicated by the presence of alite (calcium silicate) as the major mineral phase (43\%), together with the presence in excess of calcite $(27 \%)$ relative to the presence of quartz (7\%), i.e., $\mathrm{CaCO}_{3} / \mathrm{SiO}_{2}>1$, a necessary condition for alite (preferred clinker phase). The diffractogram also includes another of the four phases of the Portland cement clinker, brownmillerite or ferrite (5\%), a dark brown calcium aluminoferrite that acts as a diluent in the cement, as well as free mica minerals, muscovite $(10 \%)$, which significantly affect the plasticity index, compacted density and strength of the cement. Together with the clinker, the ground gypsum $(8 \%)$ is the second component of PC (Figure $4 \mathrm{a})$.

Natural, locally available granite-based sand was also used to produce the concrete (Figure $4 \mathrm{~b}$ ). The minerals detected in the analysis are specific to granitic rocks: Quartz $(38 \%)$, sodium plagioclase, albite (19\%), potassium feldspar, microcline (16\%), and white mica muscovite (16\%). Clay minerals indicative of mineral alteration, such as chamosite $(7 \%)$ and antigorite $(4 \%)$ also appeared in high proportions, suggesting the presence of a weathered granitic material with mechanical properties intermediate between soil and sound rock.

The specimens of granite and concrete used in this study exhibited an open porosity of approximately $3 \%$ and $20 \%$, respectively. Porosity was determined by vacuum water absorption of samples in accordance with UNE-EN 1936 [21].

Specimens of granite and concrete $\left(4 \times 4 \times 1.5 \mathrm{~cm}^{3}\right)$ with bush hammered finish were coated with layers of each selected colour of graffiti spray paint following the method described by Sanmartín and Cappitelli [2] (Figure 3). Once painted and dried, the specimens were sterilized following the protocol described by Sanmartín et al. [10]. NA contact agar plates were incubated at $28^{\circ} \mathrm{C}$ for $48 \mathrm{~h}$ to check the correct sterilization of the specimens, as confirmed by the absence of colony forming units.

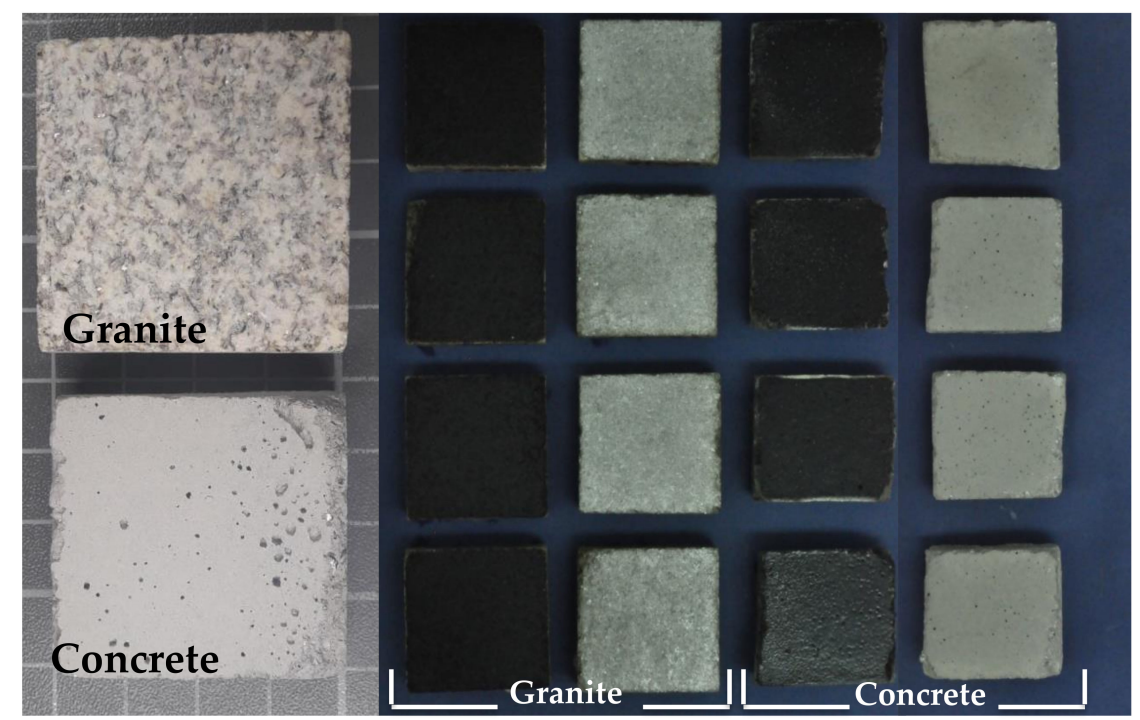

Figure 3. Uncoated and coated specimens of natural and man-made stone. 


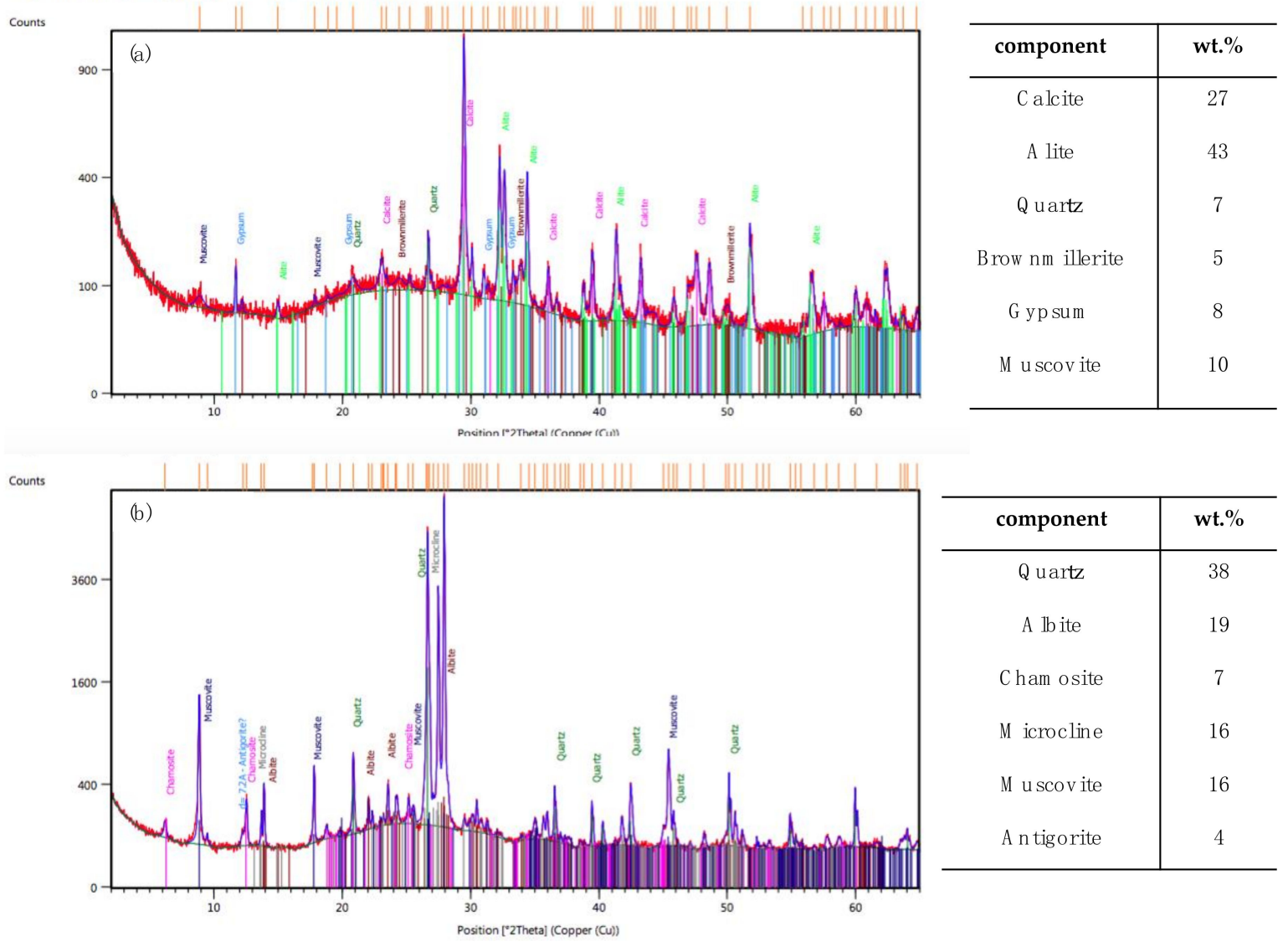

Figure 4. Mineralogical composition of concrete specimens revealed by X-ray diffraction (XRD) analysis: (a) Cementitious part, (b) sandy part.

\subsection{Biocleaning Assays with the Adapted Microorganisms}

The following methodological aspects were tested in the present study: Two carriers (cotton and $2 \%$ agar powder, Scharlab, Barcelona, Spain); two application solutions (M9 mineral medium and water); and three bacteria (Pseudomonas stutzeri 5190, Aerobacter aerogenes 13048, and Comamonas sp. 700440.

Previous studies concerning the bioremoval of graffiti have been carried out using immersion strategies $[9,10]$. As this protocol does not allow on site application, we tested the use of carriers to apply the bacteria. According to previously reported findings [22,23], we tested cotton and warm agar as carriers.

The bacteria were first adapted to (grown with) the powdered graffiti before their capacity to degrade the powder was tested. The degradative capacity of the bacteria adapted to (grown on) the painted specimens of concrete and granite was also tested.

A uniform layer of the selected adapted bacterial suspensions was applied with a sterile brush to the granite and concrete specimens previously coated with silver and black graffiti spray paint. The bacterial suspensions were prepared as follows: $100 \mathrm{~mL}$ of the bacterial suspensions grown for 20 and 23 days with powdered graffiti (protocols 1 and 2, respectively. Section 2.1) were centrifuged (4200 rpm for 10min); the pellet was resuspended in $5 \mathrm{~mL}$ of $\mathrm{M} 9$ medium or in $5 \mathrm{ml}$ of sterile water. The final cell concentration was about $10^{8} \mathrm{CFU} / \mathrm{mL}$. One $\mathrm{ml}$ of the cell suspension was applied to each stone specimen with the aid of a micropipette and sterile brush. A piece $\left(4 \times 4 \mathrm{~cm}^{2}\right)$ of humidified cotton or $6 \mathrm{~mL}$ of warm agar was immediately added (the tape was applied around the specimens to prevent spillage of agar drops, see Figure 5). All of the samples were then placed on a plastic tray and covered with plastic film to prevent the suspensions drying out. The treatments were applied inside a Laminar flow hood in order to minimise ambient contamination. For each experiment, controls 
were prepared by adding water (instead of bacterial suspension) to the surface of the specimens and delivery system. Each treatment was carried out in triplicate.

The treated and control specimens were held for 20 days at room temperature. The carriers were then removed, and the painted surfaces of the specimens were cleaned with sterile water and a sterile brush. The specimens were then allowed to dry to ensure that no live microorganisms remained on the treated surface. The absence of microorganisms on the treated surfaces was confirmed using NA contact plates, as before.
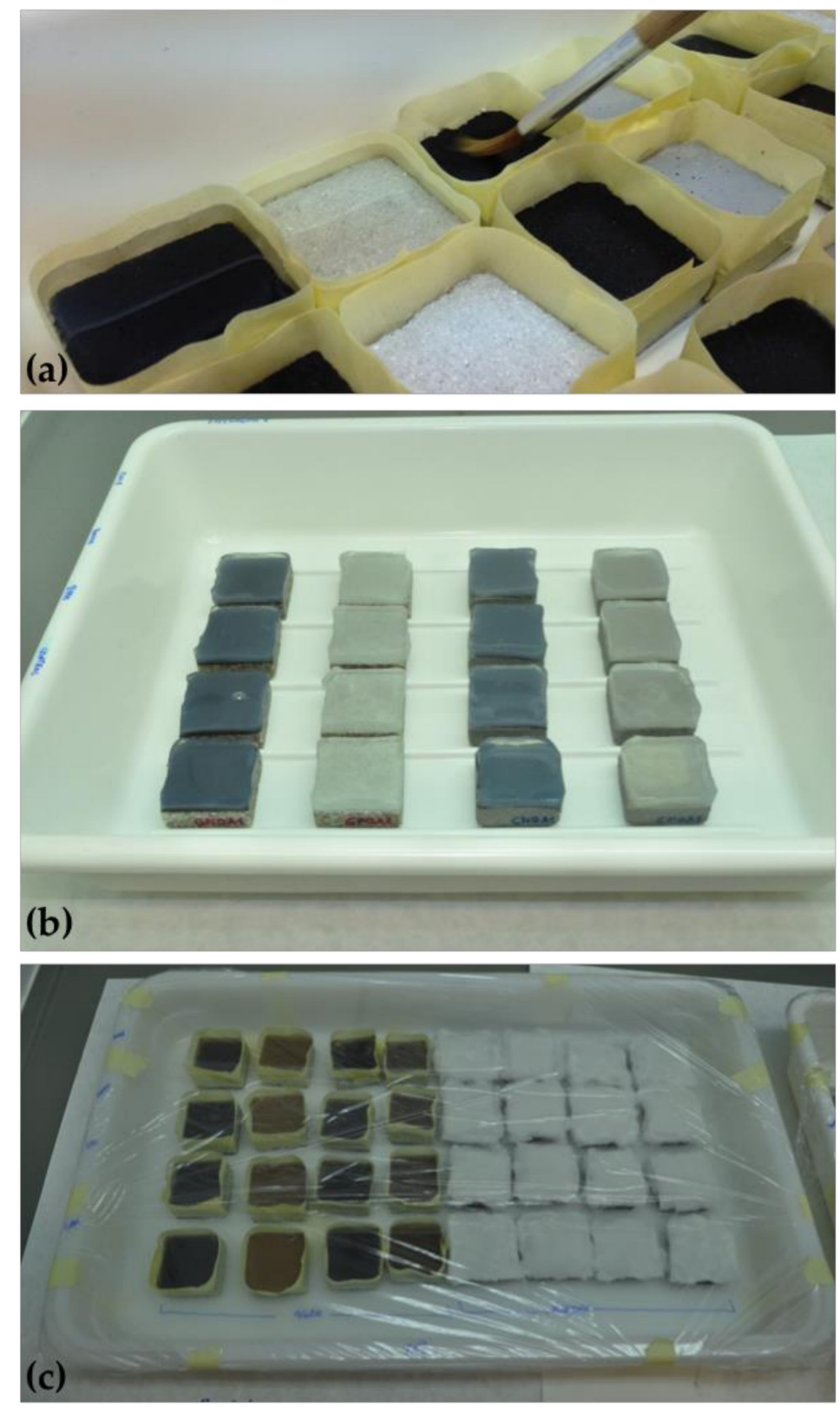

Figure 5. Biocleaning treatment with agar and cotton carriers on natural and man-made painted stone specimens. (a) Bacterial suspensions were brushed on to the layer of paint on the stone specimens and the warm agar was then added; (b) agar-treated stone specimens; (c) stone specimens treated using agar (left) and cotton (right) carriers and covered with plastic film.

\subsection{Evaluation of Bacterial Degradation of Powdered Graffiti and Painted Specimens}

CFU counting, visual and optical microscopy analysis and measurements of colour and Fourier transform infrared spectroscopy (FTIR) were used to evaluate the presence of the selected bacteria 
in the samples and the potential degradation of graffiti with (1) powdered graffiti and (2) painted test specimens.

The number of CFUs was calculated to evaluate bacterial growth during the experimental period. Thus, every three days $1 \mathrm{~mL}$ of each bacterial suspension was serially diluted and plated on nutrient agar, which was incubated for $24 \mathrm{~h}$ at $28^{\circ} \mathrm{C}$. After the treatments, the bacterial viability was determined by contact plates containing Nutrient Agar. The contact plates were placed on each specimen and then incubated at $28^{\circ} \mathrm{C}$ for $24 \mathrm{~h}$.

The samples (powered graffiti and stone specimens) were periodically evaluated by visual inspection and macroscopic photography (Nikon D90 camera with Nikon DX SWM VR Aspherical objective, Nikon Group, Tokyo, Japan).

The samples were examined by optical microscopy (NIKON 283,008 with a digital camera, Nikon Group, Tokyo, Japan) by placing the specimens directly on the microscope stage.

Colour measurements were made with a portable chroma meter (CR-300, Konica Minolta, C Minolta, Osaka, Japan) with a $8 \mathrm{~mm}$-diameter viewing area in the measuring head. Previously described methods, from which we know the minimum number of measurements required, were used for the powered graffiti [24] and the painted stone specimens [2]. The measuring conditions were as follows: (1) Diffuse illumination geometry with the specular component included in $0^{\circ}\left(d / 0^{\circ}\right)$ relative to normal, (2) illuminant D65, and (3) observer $2^{\circ}$. Colour measurements were analysed by considering the CIELAB colour system [25], which represents each colour by means of three scalar parameters or the Cartesian coordinates: $L^{*}$, lightness or luminosity of colour, which varies from 0 (absolute black) to 100 (absolute white); $a^{*}$, associated with changes in redness-greenness (positive $a^{*}$ is red and negative $a^{*}$ is green); and $b^{*}$, associated with changes in yellowness-blueness (positive $b^{*}$ is yellow and negative $b^{*}$ is blue). The partial $\left(\Delta L^{*}, \Delta a^{*}\right.$ and $\left.\Delta b^{*}\right)$ and the total $\left(\Delta E_{\mathrm{ab}}^{*}=\left(\Delta L^{* 2}+\Delta a^{* 2}+\Delta b^{* 2}\right)^{1 / 2}\right)$ colour differences between the treated (control non-inoculated and inoculated with the three bacteria) and untreated powdered graffiti power and painted specimens (silver and black) were calculated.

According to the applied colorimetry criteria, a colour difference that reaches from between 0.73 and 1 CIELAB units is an approximate threshold, or just a perceptible colour difference [26,27], while a colour difference of around 1.75 CIELAB units is defined as the 'supra-threshold' [28]. Above 3.0 CIELAB units, colour differences are considered 'widely perceptible' to any observer with normal vision [26,27] and colour differences between 5.0 and 6.0 CIELAB units are considered 'large colour differences' [29].

Chemical changes due to the presence of bacteria on the graffiti paint and degradation of graffiti paint induced by the bacteria were evaluated by infrared Fourier transform (FTIR) transmittance spectroscopy. The spectra were obtained using a spectrophotometer (VARIAN FTIR 670, Palo Alto, CA, USA), in the spectral range of the medium $\left(400-4000 \mathrm{~cm}^{-1}\right)$ and a resolution of $4 \mathrm{~cm}^{-1}$. In the powdered graffiti samples, $0.01 \mathrm{~g}$ of powdered paint was dispersed in $0.19 \mathrm{~g}$ of $\mathrm{KBr}$, with the aid of an agate mortar and pestle, to form a translucent pellet, which was analysed by IR. For the stone specimens, a platinum-ATR-sampling module (equipped with diamond crystal, edged in tungsten carbide, and mounted on a stainless-steel plate) was used. The data were processed with OPUS software (Version 3.x, Cooperative Library Network of Berlin-Brandenburg (KOBV), Berlin, Germany) by constructing the spectra, locating the peaks and comparing them with the spectra in our own and published reference databases.

\section{Results}

\subsection{Powdered Graffiti}

In both protocols tested, the bacteria grew successfully with powdered graffiti for 20 and 23 days. There were no significant differences between the protocols in terms of the number of bacteria obtained $(\mathrm{CFU} / \mathrm{mL})$. Therefore, growth protocol 1 should be selected for future experiments because it is faster ( 3 days less) and easier (only one culture media step) and also ensures that bacteria use graffiti components as a carbon source. 
Examination of the specimens by the visual and optical microscopy revealed the formation of biofilm around the particles of powdered graffiti (Figure 6), indicating that the bacteria were trying to degrade the graffiti.

The colour variations in the powdered graffiti (Table 1) showed widely perceptible total colour changes $\left(\Delta E_{\mathrm{ab}}^{*}\right)$, of more than 3 CIELAB units (see Section 2.4.), with all bacterial treatments, except for black paint treated with Comamonas sp. 700440. The species Pseudomonas stutzeri 5190 and Aerobacter aerogenes 13,048 produced the greatest variations in colour, with both silver and black paint.

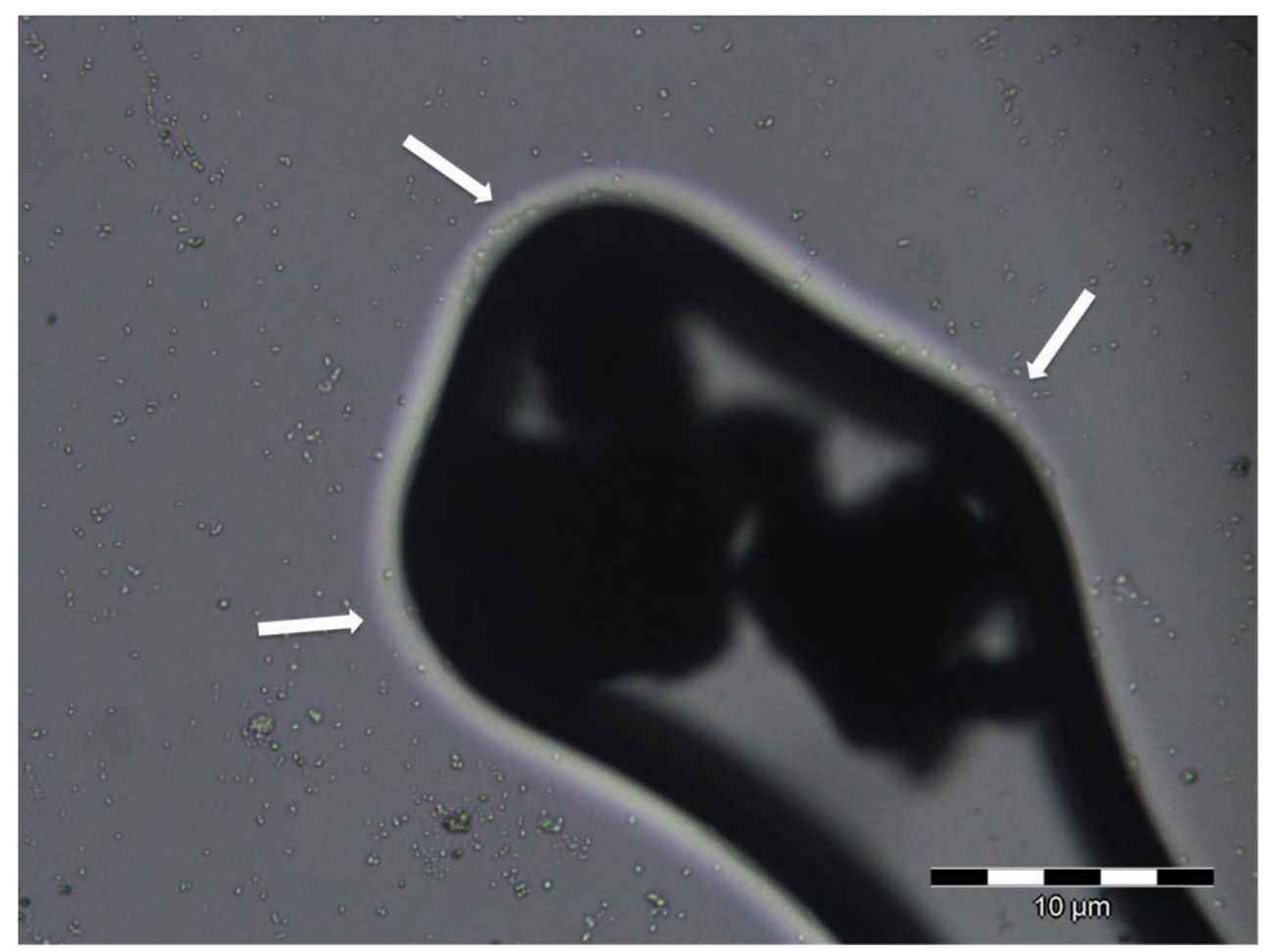

Figure 6. Micrograph of particles of powdered graffiti surrounded by biofilm (white arrows).

Table 1. Partial colour differences $\left(\Delta L^{*}, \Delta a^{*}\right.$ and $\Delta b^{*}$, CIELAB units) and total colour difference $\left(\Delta E^{*}{ }_{a b}\right.$, CIELAB units) between the powdered graffiti.

\begin{tabular}{|c|c|c|c|c|}
\hline Silver Graffiti Paint & Control $^{1}$-Paint ${ }^{1}$ & $5190^{1}$-Paint $^{1}$ & $13048^{1}$-Paint $^{1}$ & $700440^{1}$-Paint ${ }^{1}$ \\
\hline$\Delta L^{*}$ & -2.0 & -4.5 & -4.2 & -3.7 \\
\hline$\Delta a^{*}$ & 0.0 & 0.1 & 0.0 & 0.1 \\
\hline$\Delta b^{*}$ & 0.8 & 1.3 & 0.5 & 1.1 \\
\hline$\Delta E_{\mathrm{ab}}^{*}$ & 2.1 & 4.6 & 4.2 & 3.8 \\
\hline Black Graffiti Paint & Control $^{1}$-Paint ${ }^{1}$ & $5190^{1}$-Paint $^{1}$ & $13048^{1}$-Paint $^{1}$ & $700440^{1}$-Paint ${ }^{1}$ \\
\hline$\Delta L^{*}$ & -1.9 & 5.7 & 8.4 & 1.4 \\
\hline$\Delta a^{*}$ & 0.0 & -0.1 & -0.3 & -0.2 \\
\hline$\Delta b^{*}$ & -0.5 & -0.5 & -1.6 & -1.0 \\
\hline$\Delta E_{\mathrm{ab}}^{*}$ & 2.0 & 5.7 & 8.6 & 1.7 \\
\hline
\end{tabular}

${ }^{1}$ Paint, graffiti spray paint; control, without bacteria; 13,048 corresponds to Aerobacter. aerogenes; 700,440 corresponds to Comamonas sp., 5190 corresponds to Pseudomonas stutzeri.

The FTIR-spectra of the powdered graffiti samples treated using protocol 1 (Figures 7 and 8) revealed the presence of the bacteria tested (marked in red in the figures) and their components: Water, lipid, protein, and carbohydrate. This was especially marked in silver spray paint, in which in addition to the band corresponding to the $\mathrm{O}-\mathrm{H}$ stretching vibration from water at $3500-3000 \mathrm{~cm}^{-1}$ appeared, peaks appeared at $3010 \mathrm{~cm}^{-1}$, corresponding to lipids and fatty acids [30], at $1620 \mathrm{~cm}^{-1}$ 
corresponding to the beta-sheet, secondary structure in proteins [31], and at $1040 \mathrm{~cm}^{-1}$, corresponding to polysaccharides [32]. By contrast, major damage due to biodeterioration (marked in blue in the figures) appeared to occur in the black paint, although the FTIR-spectra revealed that Pseudomonas stutzeri 5190, Aerobacter aerogenes 13,048 and Comamonas sp. 700,440 were able to induce chemical changes in both graffiti paints, as observed in the FTIR-spectra in the form of decreasing intensity of the peaks of the bands of alkanes at 2920 and $2850 \mathrm{~cm}^{-1}$ and carbonyl group at $1716 \mathrm{~cm}^{-1}$ [17], carbon-carbon triple bond at $2249 \mathrm{~cm}^{-1}$ and esters of fatty acids at $1250 \mathrm{~cm}^{-1}$ [33]. Furthermore, Aerobacter aerogenes 13048, which caused the greatest changes in the colour of the black graffiti paint, seems to have induced the greatest chemical changes, although the differences were slightly relative to those caused by the other two bacteria.

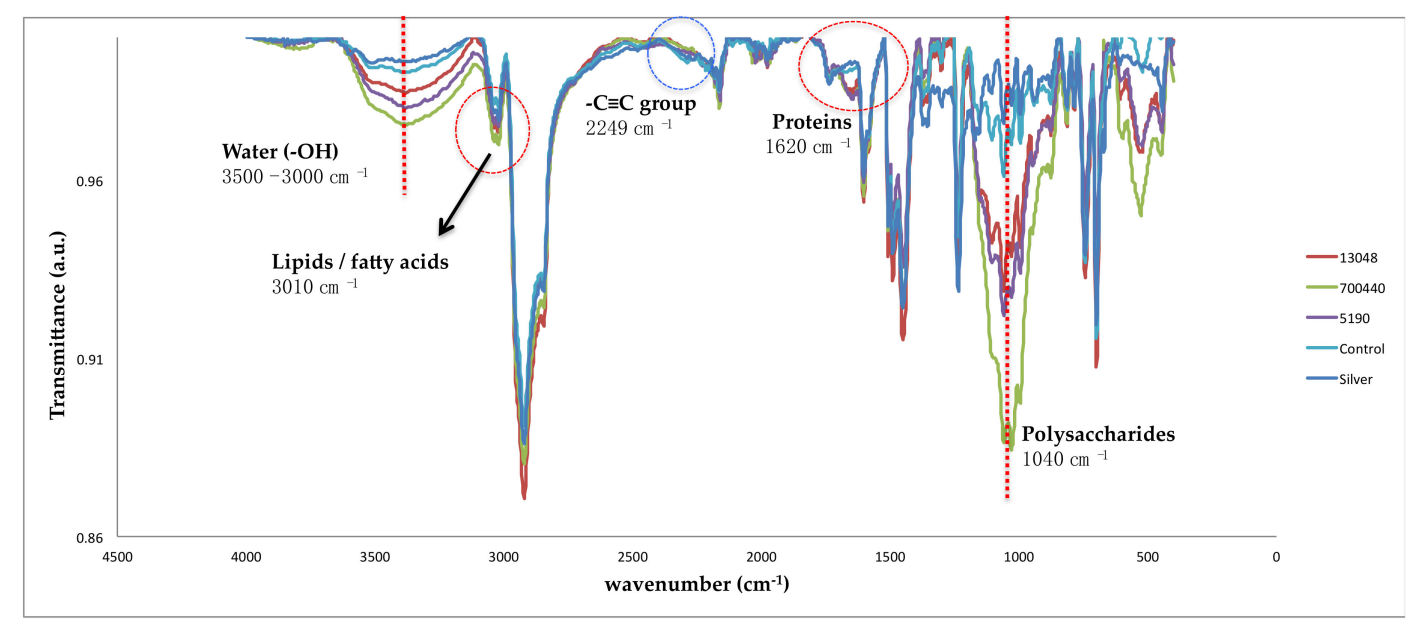

Figure 7. Infrared spectra of silver powdered graffiti after treatment with bacteria. Silver graffiti spray paint; control, without bacteria; 13,048 corresponds to Aerobacter aerogenes; 700,440 corresponds to Comamonas sp., and 5190 corresponds to Pseudomonas stutzeri.

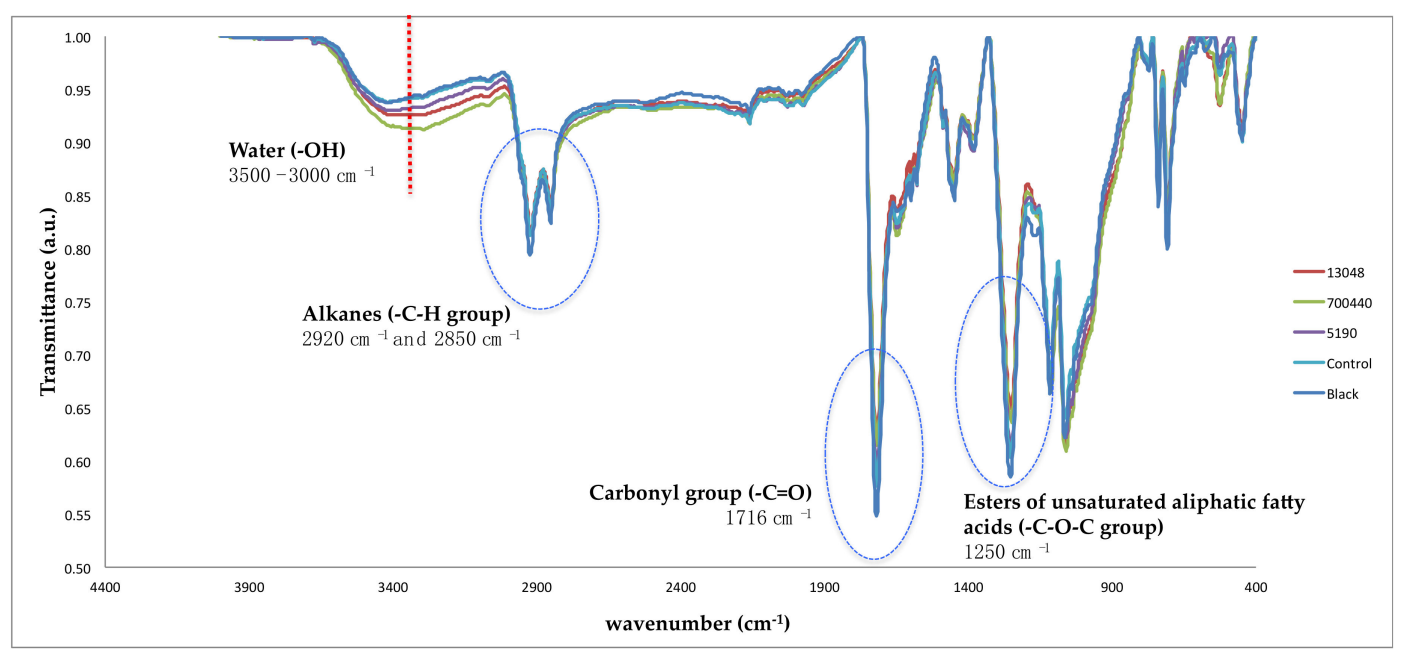

Figure 8. Infrared spectra of black powdered graffiti after treatment with bacteria. Black graffiti spray paint; control, without bacteria; 13,048 corresponds to Aerobacter aerogenes; 700,440 corresponds to Comamonas sp., and 5190 corresponds to Pseudomonas stutzeri.

\subsection{Graffiti Coated Stone and Concrete Specimens}

Tests showed agar to be the most suitable carrier. While the agar remained humid throughout the experimental period (20 days), water had to be added to the cotton approximately every five days. The cotton was also more readily contaminated by ambient fungi than the agar. The agar was easily 
removed at the end of the treatment, while cotton threads remained stuck on the painted specimens. Carrier removal was controlled by optical microscopy as described by Bosch-Roig et al. [23].

Regarding the application solution, there were no differences in the biocleaning efficiency in relation to the use of M9 mineral media or sterile water.

In some samples, visual examination revealed colour changes in the layer of silver graffiti and small holes in the layer of black graffiti (Figure 9).

Analysis of the bacterial viability after the treatments revealed bacterial growth in all contact plates sampled, indicating that the application protocol enabled the bacteria to survive during the 20 days duration of the treatment.

The results of the colorimetric analysis (Tables 2 and 3), considering $\Delta E^{*}{ }_{a b}$, indicated that the colour differences produced by the bacteria in black graffiti (on granite and concrete) were just perceptible [26,27], while in the silver graffiti the colour changes were greater. In the concrete specimens covered by silver paint, $\Delta E^{*}$ ab values of between 4 and 6 CIELAB units were obtained, with $\Delta L^{*}$ sometimes being negative and sometimes positive, indicating that the specimens darkened and lightened indistinctly. For granite and silver paint, differences of up to 15 CIELAB units were observed in some cases, with $\Delta L^{*}$ always being negative, indicating darkening due to bacteria. These colour changes apparently occurred independently of whether the specimens were inoculated with bacteria or not.

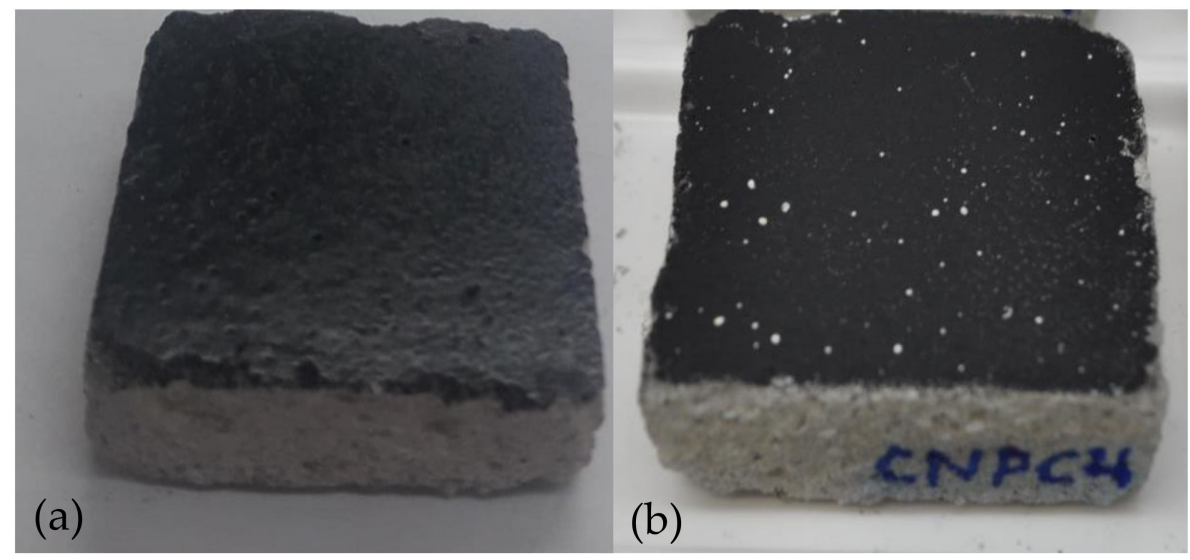

Figure 9. (a) The black graffiti layer on concrete and (b) after the biocleaning treatment (20 days).

Table 2. Partial colour differences $\left(\Delta L^{*}, \Delta a^{*}\right.$ and $\Delta b^{*}$, CIELAB units) and total colour difference $\left(\Delta E^{*}{ }_{\mathrm{ab}}\right.$, CIELAB units) between the painted specimens of natural granite stone.

\begin{tabular}{|c|c|c|c|c|}
\hline Silver Graffiti Paint & Control $^{1}$-Paint ${ }^{1}$ & $5190^{1}$-Paint ${ }^{1}$ & $13048^{1}$-Paint $^{1}$ & $700440^{1}$-Paint $^{1}$ \\
\hline$\Delta L^{*}$ & -15.45 & -7.5 & -14.3 & -5.7 \\
\hline$\Delta a^{*}$ & -0.1 & -0.0 & 0.1 & -0.1 \\
\hline$\Delta b^{*}$ & 1.5 & 1.6 & 4.1 & 1.8 \\
\hline$\Delta E_{\mathrm{ab}}^{*}$ & 15.5 & 7.6 & 15.1 & 6.0 \\
\hline Black Graffiti Paint & Control $^{1}$-Paint ${ }^{1}$ & $5190^{1}$-Paint ${ }^{1}$ & $13048^{1}$-Paint $^{1}$ & $700440^{1}$-Paint $^{1}$ \\
\hline$\Delta L^{*}$ & 0.6 & 1.0 & -0.3 & 0.9 \\
\hline$\Delta a^{*}$ & -0.1 & -0.0 & -0.1 & -0.1 \\
\hline$\Delta b^{*}$ & -0.2 & 0.2 & 0.0 & -0.2 \\
\hline$\Delta E_{\mathrm{ab}}^{*}$ & 0.7 & 1.0 & 0.3 & 1.0 \\
\hline
\end{tabular}

${ }^{1}$ Paint, graffiti spray paint; control, without bacteria; 13,048 corresponds to Aerobacter aerogenes; 700,440 corresponds to Comamonas sp., and 5190 corresponds to Pseudomonas stutzeri. 
Table 3. Partial colour differences $\left(\Delta L^{*}, \Delta a^{*}\right.$ and $\Delta b^{*}$, CIELAB units) and total colour difference $\left(\Delta E_{\mathrm{ab}}\right.$, CIELAB units) between the painted specimens of man-made concrete.

\begin{tabular}{|c|c|c|c|c|}
\hline Silver Graffiti Paint & Control $^{1}$-Paint ${ }^{1}$ & $5190^{1}$-Paint ${ }^{1}$ & $13048^{1}$-Paint $^{1}$ & $700440^{1}$-Paint ${ }^{1}$ \\
\hline$\Delta L^{*}$ & -5.3 & -0.6 & 0.8 & 2.8 \\
\hline$\Delta a^{*}$ & 0.0 & 0.2 & -0.0 & -0.0 \\
\hline$\Delta b^{*}$ & 1.3 & 4.4 & 4.1 & 3.8 \\
\hline$\Delta E_{\mathrm{ab}}^{*}$ & 5.5 & 4.4 & 4.2 & 4.7 \\
\hline Black Graffiti Paint & Control $^{1}$-Paint ${ }^{1}$ & $5190^{1}$-Paint $^{1}$ & $13048^{1}$-Paint $^{1}$ & $700440^{1}$-Paint ${ }^{1}$ \\
\hline$\Delta L^{*}$ & 0.9 & -0.7 & -0.5 & -0.3 \\
\hline$\Delta a^{*}$ & -0.1 & -0.0 & -0.0 & 0.0 \\
\hline$\Delta b^{*}$ & -0.0 & 0.0 & 0.0 & 0.0 \\
\hline$\Delta E_{\mathrm{ab}}^{*}$ & 0.9 & 0.7 & 0.5 & 0.3 \\
\hline
\end{tabular}

${ }^{1}$ Paint, graffiti spray paint; control, without bacteria; 13,048 corresponds to Aerobacter aerogenes; 700,440 corresponds to Comamonas sp., and 5190 corresponds to Pseudomonas stutzeri.

The FTIR spectra obtained 20 days after the application of the biocleaning treatment showed very similar bands (indicating deterioration) to those obtained for the powdered graffiti (Figures 7 and 8), and bands indicating the presence of bacteria in some areas of the treated surface.

\section{Discussion and Final Remarks}

Graffiti removal is a difficult task involving many factors such as the type of substrate (chemical composition, texture, porosity, hardness, etc.), the degree of weathering of both the substrate and the paint and the time between application and removal of the paint. Porous substrates will remain permanently stained after graffiti removal, while plastic, glazed ceramic, metallic and glass substrates are easier to clean. In addition, high-pressure hot water and chemical solvents (traditional techniques) may penetrate the substrate and cause irreversible damage. Laser-based techniques, which are mainly applied to historical buildings and structures, also have some drawbacks, as they can visibly alter the colour of the substrate (e.g., inducing yellowing), remove some grains and produce craters, and also transform, melt and/or fracture the minerals, such as the micas in granite. Biocleaning appears to be less variable than these other treatments and is able to preserve the original patina [34].

Spraying graffiti paint onto granite and concrete, or similar building materials like marble and brick, leads to very strong bonding between the material support and the components of the graffiti paint, thus making removal very difficult. The porosity of the substrate plays an important role in the bonding, and future studies should test different surface finishes, as well as more and less porous building materials, such as metal and lime mortar, to examine the role of the interaction between the paint and the support in the biocleaning process. In the biocleaning procedure, the bacteria should degrade the organic components (binders, etc.), thus releasing the pigments and improving the results of the process. However, the strong bonding between the graffiti and the support make this difficult, as direct contact between the graffiti and the bacteria is required. Different delivery systems could be tested in future studies for a better understanding of the interaction between bacteria and the painted substrate.

Selection of the microorganisms used is an important step in the biocleaning process, and the tolerance and ability of different microbes to grow using the graffiti components as an energy source, and therefore their capacity for specialized enzymatic and physiologic responses, have been investigated [35]. The microorganisms used for bioremediation purposes are usually selected by successive growing trials on culture medium (or minimal medium) enriched with the target substance (e.g., petrol). The concentration of the target substance can be varied, and the adaptation and survival of the microorganisms evaluated [36]. In order to enhance the selection of microorganisms and their suitability for graffiti removal, an enriched liquid medium based on a minimal medium (M9) and powdered graffiti (target substance) was developed for the first time in the present study. 
This graffiti-based medium could help in the future selection of microorganisms for biocleaning purposes. Other microorganisms could also be evaluated using this medium to enhance the efficiency, specificity and speed of graffiti removal.

The cost of biocleaning is similar to the use of solvent-based chemical methods and even cheaper than new physical cleaning approaches such as laser and ultrasound. Biocleaning also provides other benefits compared to traditional methods: The selectivity of the cleaning process and the subsequent enhanced substrate integrity; the ease of the application of the process, with no need for skilled labour; the absence of toxicity, and therefore respect for environmental and human safety; and the good social/public acceptance due to the safety and sustainability of the technique. Although biocleaning provides a novel approach to graffiti removal, it remains a work in progress. Some of the limitations are still to be resolved include incomplete/partial cleaning of the graffiti, the relatively long treatment times, low efficiency of bioremoval of graffiti from man-made and stone materials, variable results with different types of substrate and colours of graffiti paint.

In this study, biocleaning assays were carried out to examine the specific applicability for each substrate-cleaner interaction, in order to propose some improvements towards developing a suitable biological protocol of action for walls and building surfaces. In this respect, the main results obtained can be summarized as follows:

- Pseudomonas stutzeri DSMZ 5190 was shown, for the first time, to be able to grow using powdered graffiti as an energy source, and it, therefore, represents a potential candidate for use in the bioremoval of graffiti.

- A liquid culture medium enriched with powdered graffiti, tested here for the first time, enhancing the selection of appropriate bacteria, thus facilitating and accelerating the ability of the microorganisms to degrade the graffiti;

- A protocol for applying the biocleaning treatment to remove graffiti from natural and man-made stone materials - based on the use of agar and water as carrier agents-is proposed.

- Finally, some improvements have been made to the existing methodology, e.g., shortening the time required for adaptation of the microorganisms and the application time, making the method easier to apply on a larger scale.

Author Contributions: P.S. and P.B.-R. conceptualization, conceived and designed the experiments and methodology; P.B.-R. supervised the research carried out by two laboratory assistants; P.S. and P.B.-R. data curation in comparison with the current literature; P.S. and P.B.-R. writing- original draft preparation; P.S. and P.B.-R.; writing-review and editing, visualization, supervision, project administration and funding acquisition.

Funding: An important part of this research was carried out in Vitruvian Technologies S.L. laboratory, thanks to a collaborative agreement. The authors are grateful to Barrié Foundation for the economic support in the purchase of some of the bacterial strains used in the study. The strains were purchased during the period of a scholarship for postgraduate studies abroad (2012 Call) granted to P. Sanmartín.

Acknowledgments: Francesca Cappitelli (Università degli Studi di Milano, Italy) who first proposed the idea on which this project is based. Vitruvian Technologies S.L. (Valencia) for their interest in the project, collaboration, and access to their laboratory where an important part of the work was conducted. Daniel Vázquez-Nion and Luis Marco Roig for assistance in the laboratory and other activities. Breixo S.L. Obras e Servicios (Santiago de Compostela, Spain) for kindly providing the specimens of concrete used in the study.

Conflicts of Interest: The authors declare no conflict of interest.

\section{References}

1. Bosch-Roig, P.; Ranalli, G. Biocleaning of cultural heritage treasures. In Biodeterioration and Preservation in Art, Archaeology and Architecture; Mitchell, R., Clifford, J., Eds.; Archetype Publications: London, UK, 2018; pp. $169-183$.

2. Sanmartín, P.; Cappitelli, F. Evaluation of accelerated ageing tests for metallic and non-metallic graffiti paints applied to stone. Coatings 2017, 7, 180. [CrossRef]

3. Final Report Summary-GRAFFITAGE (Development of A New Anti-Graffiti System, Based on Traditional Concepts, Preventing Damage of Architectural Heritage Materials); Community Research and Development Information Service, European Comission: Brussel, Belgium, 2011. 
4. Final Report Summary-EFFACEUR (InnovativE Anti-GraFFiti Product for Application in the Cultural Heritage of EURope); Community Research and Development Information Service, European Comission: Brussel, Belgium, 2013.

5. Sanmartín, P.; Cappitelli, F.; Mitchell, R. Current methods of graffiti removal: A review. Constr. Build. Mater. 2014, 71, 363-374. [CrossRef]

6. Sanmartín, P.; Mitchell, R.; Cappitelli, F. Evaluation of cleaning methods for graffiti removal. In Urban Pollution and Changes to Materials and Building Surfaces; Brimblecombe, P., Ed.; Imperial College Press: River Edge, NJ, USA, 2016; pp. 291-312.

7. Germinario, G.; van der Werf, I.D.; Palazzo, G.; Regidor Ros, J.L.; Montes-Estelles, R.M.; Sabbatini, L. Bioremoval of marker pen inks by exploiting lipase hydrolysis. Prog. Org. Coat. 2017, 110, 162-171. [CrossRef]

8. Gaylarde, C.C.; Morton, L.H.G.; Loh, K.; Shirakawa, M.A. Biodeterioration of external architectural paint films-A review. Int. Biodeterior. Biodegrad. 2011, 65, 1189-1198. [CrossRef]

9. Giacomucci, L.; Toja, F.; Sanmartín, P.; Toniolo, L.; Prieto, B.; Villa, F.; Cappitelli, F. Degradation of nitrocellulose-based paint by D. desulfuricans ATCC 13541. Biodegradation 2012, 23, 705-716. [CrossRef] [PubMed]

10. Sanmartín, P.; DeAraujo, A.; Vasanthakumar, A.; Mitchell, R. Feasibility study involving the search for natural strains of microorganisms capable of degrading graffiti from heritage materials. Int. Biodeterior. Biodegr. 2015, 103, 186-190. [CrossRef]

11. Sanmartín, P.; Cattò, C.; Bosch-Roig, P.; Troiano, F.; Cappitelli, F. Bioremediation of graffiti using novel commercial bacterial strains. Unpublished work. 2019.

12. Bosch-Roig, P.; Decorosi, F.; Giovannetti, L.; Ranalli, G.; Viti, C. Connecting phenome to genome in Pseudomonas stutzeri 5190: An artwork biocleaning bacterium. Res. Microbiol. 2016, 167, 757-765. [CrossRef] [PubMed]

13. Ranalli, G.; Zanardini, E.; Andreotti, A.; Colombini, M.P.; Corti, C.; Bosch-Roig, P.; De Nuntiis, P.; Lustrato, G.; Mandrioli, P.; Rampazzi, L.; et al. Hi-tech restoration by two-steps bio-cleaning process of Triumph of Death fresco at the Camposanto Monumental Cemetery (Pisa, Italy). J. Appl. Microbiol. 2018, 125, 800-812. [CrossRef]

14. Bosch-Roig, P.; Regidor-Rosi, J.L.; Soriano-Sancho, P.; Montes-Estellés, R.M. Biocleaning of animal glue on wall paintings by Pseudomonas stutzeri. Chim. Oggi-Chem. Today 2013, 31, 50-53.

15. Ranalli, G.; Alfano, G.; Belli, C.; Lustrato, G.; Colombini, M.P.; Bonaduce, I.; Zanardini, E.; Abbruscato, P.; Cappitelli, F.; Sorlini, C. Biotechnology applied to cultural heritage: Biorestoration of frescoes using viable bacterial cells and enzymes. J. Appl. Microbiol. 2005, 98, 73-83. [CrossRef]

16. Bosch-Roig, P.; Regidor-Rosi, J.L.; Montes-Estellés, R.M. Biocleaning of nitrate alterations on wall paintings by Pseudomonas stutzeri. Int. Biodeterior. Biodegr. 2013, 84, 266-274. [CrossRef]

17. Rivas, T.; Pozo, S.; Fiorucci, M.P.; López, A.J.; Ramil, A. Nd:YVO 4 laser removal of graffiti from granite. Influence of paint and rock properties on cleaning efficacy. Appl. Surf. Sci. 2012, 263, 563-572. [CrossRef]

18. Fiorucci, M.P.; Lopez, A.J.; Ramil, A.; Pozo, S.; Rivas, T. Optimization of graffiti removal on natural stone by means of high repetition rate UV laser. Appl. Surf. Sci. 2013, 278, 268-272. [CrossRef]

19. Sanmartín, P.; Silva, B.; Prieto, B. Effect of surface finish on roughness, color and gloss of ornamental granites. J. Mater. Civ. Eng. 2011, 23, 1239-1248. [CrossRef]

20. EN 197-1 Composition, Specification and Conformity Criteria for Common Cements; European Committee for Stadardization: Bruxelles, Belgium, 2012.

21. UNE-EN 1936:2007 Natural Stone Test Methods-Determination of Real Density and Apparent Density, and of Total and Open Porosity; AENOR: Madrid, Spain, 2007.

22. Bosch-Roig, P.; Lustrato, G.; Zanardini, E.; Ranalli, G. Biocleaning of Cultural Heritage stone surfaces and frescoes: Which delivery system can be the most appropriate? Ann. Microbiol. 2015, 65, 1227-1241. [CrossRef]

23. Bosch-Roig, P.; Regidor Ros, J.L.; Soriano Sancho, M.P.; Montes Estellés, R.; Roig Picazo, P. Biocleaning on wall paintings on uneven surfaces with warm agar gels. In Gels in the Conservation of Art; Archetype Publications: London, UK, 2017; pp. 119-121.

24. Sanmartín, P.; Silva-Sánchez, N.; Martínez-Cortizas, A.; Prieto, B. Usual and unusual CIELAB color parameters for the study of peat organic matter properties: Tremoal do Pedrido bog (NW Spain). J. Physics. Conf. Ser. 2015, 605, 012014. [CrossRef] 
25. Colorimetry; Central Bureau of the CIE: Vienna, Austria, 1986.

26. Wyszecki, G.; Stiles, W.S. Color Science. Concepts and Methods. Quantitative Data and Formulae; Wiley: New York, NY, USA, 1982.

27. Völz, H.G. Industrial Color Testing; Wiley VCH: Weinheim, Germany, 2001.

28. Melgosa, M.; Hita, E.; Poza, A.J.; Alman, D.H.; Berns, R.S. Suprathreshold color-difference ellipsoids for surface colors. Color Res. Appl. 1997, 22, 148-155. [CrossRef]

29. Hardeberg, A.Y. Acquisition and reproduction of color images: Colorimetric and multispectral approaches. Ph.D. Thesis, Ecole Nationale Superieure des Telecommunications, Paris, France, 1999.

30. Sitole, L.; Steffens, F.; Krüger, T.P.J.; Meyer, D. Mid-ATR-FTIR spectroscopic profiling of HIV / AIDS sera for novel systems diagnostics in global health. OMICS J. Integr. Biol. 2014, 18, 513-523. [CrossRef]

31. Kong, J.; Yu, S. Fourier transform infrared spectroscopic analysis of protein secondary structures. Acta Biochim. Biophys. Sin. 2007, 39, 549-559. [CrossRef]

32. Houari, A.; Seyer, D.; Kecili, K.; Heim, V.; Di Martino, P. Kinetic development of biofilm on NF membranes at the Méry-sur-Oise plant, France. Biofouling 2013, 29, 109-118. [CrossRef]

33. Socrates, G. Infrared and Raman Characteristic Group Frequencies: Tables and Charts, 3rd ed.; Wiley: Oxford, UK, 2001.

34. Cappitelli, F.; Toniolo, L.; Sansonetti, A.; Gulotta, D.; Ranalli, G.; Zanardini, E.; Sorlini, C. Advantages of using microbial technology over traditional chemical technology in the removal of black crusts from stone surfaces of historical monuments. Appl. Environ. Microbiol. 2007, 73, 5671-5675. [CrossRef] [PubMed]

35. Atlas, M.R.; Horowitz, A.; Krichevky, M.; Bej, K.A. Response of microbial population to environmental disturbance. Microbiol. Ecol. 1991, 22, 249-256. [CrossRef] [PubMed]

36. Rivera, M.C.; Ferrera, R.; Volke, V.; Rodríguez, R.; Fernández, L. Adaptación y Selección de Microorganismos Autóctonos en Medios de Cultivos Enriquecidos con Petróleo Crudo. Terra Latinoamericana 2002, 20, 423-434. (In Spanish)

(C) 2019 by the authors. Licensee MDPI, Basel, Switzerland. This article is an open access article distributed under the terms and conditions of the Creative Commons Attribution (CC BY) license (http:/ / creativecommons.org/licenses/by/4.0/). 